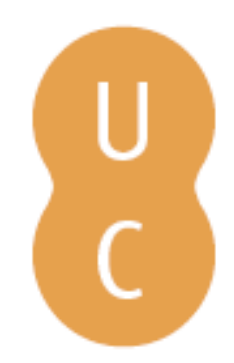

\title{
pompalina
}

\section{Callimachus and the New Paths of Myth}
Autor(es):
Várzeas, Marta
Edições Afrontamento; CITCEM - Centro de Investigação Clássicos e Humanísticos; Alexandria University; Imprensa da Universidade de Coimbra
Publicado por: Transdisciplinar «Cultura, Espaço e Memória»; Centro de Estudos
URL persistente:
URI:http://hdl.handle.net/10316.2/36172
DOI:
DOI:http://dx.doi.org/10.14195/978-989-26-0966-9_11
Accessed : $\quad$ 26-Apr-2023 10:44:19

A navegação consulta e descarregamento dos títulos inseridos nas Bibliotecas Digitais UC Digitalis, UC Pombalina e UC Impactum, pressupõem a aceitação plena e sem reservas dos Termos e Condições de Uso destas Bibliotecas Digitais, disponíveis em https://digitalis.uc.pt/pt-pt/termos.

Conforme exposto nos referidos Termos e Condições de Uso, o descarregamento de títulos de acesso restrito requer uma licença válida de autorização devendo o utilizador aceder ao(s) documento(s) a partir de um endereço de IP da instituição detentora da supramencionada licença.

Ao utilizador é apenas permitido o descarregamento para uso pessoal, pelo que o emprego do(s) título(s) descarregado(s) para outro fim, designadamente comercial, carece de autorização do respetivo autor ou editor da obra.

Na medida em que todas as obras da UC Digitalis se encontram protegidas pelo Código do Direito de Autor e Direitos Conexos e demais legislação aplicável, toda a cópia, parcial ou total, deste documento, nos casos em que é legalmente admitida, deverá conter ou fazer-se acompanhar por este aviso.

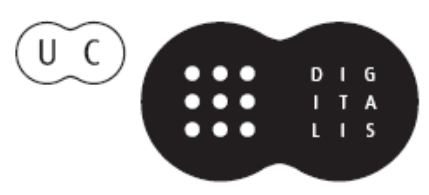




\title{
CALLIMACHUS AND THE NEW PATHS OF MYTH
}

\author{
MARTA VÁRZEAS
}

University of Oporto. Centro de Estudos Clássicos e Humanísticos (University of Coimbra).

\begin{abstract}
Callimachus presents himself as a teller of myths, of ancient stories told by others before. Some of his Hymns are a parody on the traditional narratives where the main characters are gods and which were passed on by poets, starting with Homer and Hesiod. This paper aims at analysing passages in the Hymns that demonstrate the poet's constant dialogue with the past and tradition, namely with Homer.
\end{abstract}

The only integral part of Callimachus's works known to us, thanks to a continuous manuscript tradition throughout the ages, is a collection of six Hymns, the organisation of which is generally assumed as an editorial decision by the poet ${ }^{1}$. Although Callimachus's Hymns are rooted in the artistic tradition of the Homeric Hymns, mostly composed in the Archaic Period for public performances on the occasion of the great festivities, by aoidoi claiming to be descendants of the great epic poet, these compositions by the poet from Alexandria were not meant for public performance (an idea generally accepted by critics nowadays); they were destined to be read, notwithstanding the oral presentations at the Museum in which Callimachus was involved.

Hellenistic poetry is purported to be essentially mimetic and erudite. In Callimachus's case, there were underlying circumstances that explained those characteristics: since he

\footnotetext{
${ }^{1}$ DEPEW, 2004: 117, for instance, argues that Callimachus most likely organized the hymns into book form, since both his Iambi and Aitia had also been arranged in book format. Cf. PFEIFFER, 1949; HOPKINSON, 1984.
} 
worked at the Alexandria Library and probably collaborated on the edition of the texts by some ancient poets, such Pindar, he had access to most, if not all, of the literary heritage of the Hellas. In fact, a careful reading of the Hymns conveys their palimpsestic quality, with several noticeable textual layers of distinct authors and literary genres - Homer, Hesiod, Pindar, Bacchylides, among others. Callimachus uses the traditional hymnic form, applied both to the structure and to the metric scheme, which is the dactylic hexameter (except for the hymn to Athena, written in couplets) of the Homeric Hymns, the most obvious source of inspiration for these texts. In the so-called mimetic hymns ${ }^{2}-$ to Apollo, to Athena and to Demeter - he even "pretends» the traditional performance context of this type of compositions, but his poems are full of intertextual references perceptible only in a reading context, rather than in a hearing context ${ }^{3}$. Moreover, his poetry does not refer to the real world, in opposition to the Homeric Hymns, the narratives of which explained the origins of rituals and cults, and explained the present by evoking past events. In fact, Callimachus's Hymns build a world of words, with abundant references to other words $s^{4}$. Once there is no interest in establishing analogies with reality, the constant poetic, intertextual, allusions that characterize them are a form of engaging the reader in the poetic universe. Art is not mimesis tou biou, instead it imitates itself, in a constant dialogue with the past and tradition.

No doubt this dialogue has often a good-humoured tone; since these are poetic compositions centred on gods, such a tone underscores, in my opinion, a specific purpose - on the one hand, to reply to the old attacks on poets because of their lies about deities, construed as antropomorphic and comparable with the worst and most ridiculous specimens of the human race; on the other hand, to reply to the interpretation of myths as allegories or historical reminiscences, widely known in this age, on which he seems to have engaged in polemics, judging from what is said in the first composition of his book of Iambi. I will focus on these two aspects.

Some of Callimachus's Hymns are in fact a parody on the traditional narratives where the main characters are gods and which were passed on by poets, starting with Homer and Hesiod. As is well known, the latter were violently criticized by Heraclitus and Xenophanes.

\footnotetext{
2 On mimetic hymn, notice the definition given by MORRISON, 2007: 109: "The term "mimetic" is used in this way to describe a narrator who does not stand in the conventional relationship of narrator to audience in a hymn, but appears as a fictional character who addresses himself or other fictional characters, rather than the audience of the hymn, in the case of the Hymns one who presents himself as a participant in a ritual, and gives the audience the sense of witnessing a festival in progress». BULLOCH, 1985: 6 states that «the mimetic hymn, purported to be what is actually said by an organiser of a celebration, belongs to a distinct class of Alexandrian experimental poetry, literary drama». Cf. HUNTER, FUHRER, $2002: 146$. ${ }^{3}$ Cf. HUTCHINSON, 1988: 63. In the composition of hymns, new texts are intertwined with ancient texts and at the same time each poem is interwoven with all the others. HUNTER, FUHRER, 2002: 145 point out that in the book of Hymns, Callimachus created «a dynamic system, a "language" if you like, in which each poem and each divinity may be read in relation to all others». Cf. HARDER, 1992.

${ }^{4}$ This is DEPEW's $(1989,1998)$ viewpoint: she argues that the use of the aition by Callimachus does not imply any relation with the extratextual world, but rather establishes a link between past and present texts.
} 
These authors never abandoned the quest for the appropriate discourse to speak of divinity; such a quest is also pursued by great poets like Pindar or the tragic poets - Aeschylus, Sophocles and, in his own way, Euripides. In Pindar's case, for example, the search for the words and register adequate to the expression of the divine stems from the identification of poetry with truth, characteristic of his aesthetic universe; although this notion is seminally found in Hesiod, it is one of the central themes of the pindaric epinikia. Pindar views the morally inconceivable as falsehood and creates truthful narratives, thus presenting himself as a maker of myths, which enables him to fulfill the noble mission of teaching, an ancient prerogative of poets in the polis.

Callimachus, on the other hand, presents himself as the teller of myths, of ancient stories told by others before; he too selects some of the ancient versions, but does not find any incompatibility between falsehood and poetry. In his Hymn to Zeus, the first one in his book, after the three verses introducing the theme of the poem - at libations to Zeus what else should rather be sung than the god himself, mighty for ever, king for evermore - the poet alludes to a polemic that sets the question of truth and falsehood of mythical narratives at the very centre of these initial considerations (4-9):

How shall we sing of him - as lord of Dicte or of Lycaeum? My soul is all in doubt, since debated is his birth. O Zeus, some say that thou wert born on the hills of Ida; others, O Zeus, say in Arcadia; did these or those, O Father lie? «Cretans are ever liars». Yea, a tomb, O Lord, for thee the Cretans builded; but thou didst not die, for thou art for ever.

He then procedes to tell the «true» story of Zeus's birth - not the version told by the Cretans but the one told by the Arcadians. What are the grounds for the poet's claim of truth? Apparently, toponymy: for the Arcadians called a certain spot of the mountain the old place where Rheia gave birth. That is therefore Zeus's birthplace. The name given by the Cretans to the Omphalion plane also indicates that that is the place where the umbilical chord fell from Zeus's omphalos, while the nymph Neda took him to Crete, where he would be secretly reared away from his frightful father's sight.

However, the same logical inconsistencies in the Cretan story, which are the reason behind the poet's rejection of this version in favour of the Arcadian version, become apparent in the poet's own explanation, intentionally riddled with contradictions. For instance, the repetition of the adverb ócí «always» used with the verb cí $\mu$ «to be» highlights the most relevant ontological characteristic of the gods, which Homer referred to by the epithet-for-

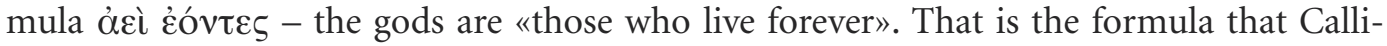
machus herein evokes and uses as a logical argument against Zeus' death, implied by the construction of a tomb by the Cretans. But this logic is flawed by the tale of the god's birth:

\footnotetext{
${ }^{5}$ English translations are from the Loeb edition of Callimachus' Hymns.
} 
after asserting the eternal greatness and sovereignty of the god- mighty for ever, king for evermore - he begins the narration of how baby Zeus was delivered from his mother's womb and, like an ordinary human newborn baby, had to be washed, and cleaned, his umbilical cord falls onto the ground, and then is cared for by a number of beings, such as the goat Amaltheia, which nurses him, and the Panacrian bee, which on Mount Ida feeds him honey, at the place named after it - Panacra. The purpose of these playful narratives is also recognizable in the poet's version of Zeus' birth, while invoking him as Jó $\tau \varepsilon \varrho$ and as

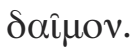

The topic of truth and falsehood is explicitly mentioned in some verses further on, when openly criticising Homer - namely the excerpt in the Odyssey where Poseidon mentions the division by lot among the three brothers, stating that Zeus was given the Olympus, Poseidon the seas and Hades the underworld. Callimachus says that old poets did not speak the truth (61-65):

For they said that the lot assigned to the sons of Cronus their three several abodes. But who would draw lots for Olympos and for Hades - save a very fool? For equal chances should one cast lots; but these are the wide world apart. When I speak fiction, be it such fiction as persuades the listener's ear!

Apart from paraphrasing Homer, these verses not only criticise the lies of the ancient poets but quite clearly echoe Pindar, as well as Hesiod and even Solon, who once remarked

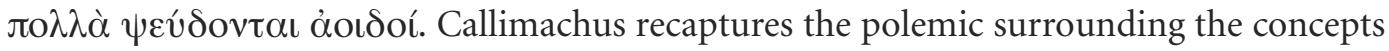
of false and true and their relevance to the reflection on the statute and role of poetry and poets in the polis. The poet from Alexandria claims to reject certain mythical versions, just like Pindar, but the criteria he uses to single out a particular version seem to be dictated common sense, as remarked by Hutchinson ${ }^{6}$. It is this appeal to common sense, implicit in the arguments and void of any moral sense, that betrays the irony in the way he addresses the issue and shows that the poet is, in fact, not interested in the polemic. The humour in Callimachus' approach to the elements typical of the narratives about gods ${ }^{7}$ highlights his detachment from the moral tones in the well-known debate on poetry and poets, and turns the topic of truth and falsehood into a rhetorical topic of hymnal discourse. Falsehood even appears to be a necessary condition for poetry and does not need, in Callimachus' aesthetic universe, to be justified by the greater good. Unlike Hesiod, Callimachus prefers to be inspired by the Muses who «know how to say lies similar to truth». However, when he explicitly mentions his addressee as someone to be persuaded by lies if necessary, he dis-

\footnotetext{
${ }^{6}$ HUTCHINSON, 1988: 66.

${ }^{7}$ HUTCHINSON, 1988: 64-66 also stresses Callimachus' playful and bewildering account of narrative elements typical of traditional hymns, such as the references to the birth and childhood of celebrated gods.
} 
tances himself from the educational, pedagogical role of poetry in the past - of which Pindar is a supreme symbol - and recognizes his art as the art of fabricating a verisimilar narrative. On the other hand, the explicit allusions to different versions of the same history constantly remind the reader that what he reads is nothing but a story ${ }^{8}$, a narrative fabricated by the poet's art, the art of narrating received by tradition.

Concerning toponymical references, Callimachus mentions names of places and their meaning in almost every hymn, thus fulfilling one of the classic functions of myth - the aetiological function. As illustrated by the examples herein and many others, like those abundantly found in the Hymn to Delos ${ }^{9}$, aetiology expresses, in my opinion, the curiosity, astonishment and fun that we also experience when we learn the origin of names like those of the Aegean Sea, the Icarus Sea, or the Bosphorus and so on ${ }^{10}$. More than a display or erudition, it seems to me that, at least in his poetic work ${ }^{11}$, Callimachus is interested in toponymy and the names of things in general because they uncover a distant world, not the world from the real or historical past but rather the «once upon a time» world, the incantatory power of which is the poetic matter par excellence. The myths disclose a wonderful world behind the surrounding reality. While a poet such as Pindar claimed that his mission was to unveil the truth beneath the appearance of things, Callimachus' purpose is to evoke the fictional universe inscribed in the names of things. Therein lies his interest in aetiology: aetiology is a way to teach ancient stories. It is not the past that explains the present, it is the present that takes us back to the fantasy of the past.

Therefore Callimachus does not reject the anthropomorphic image of gods in ancient poetry tradition, nor does he reject some all-too-human stories portrayed by them. Judging by the Hymns, he seems indeed to prefer them, and the more laughable the better.

I will give one more example: the Hymn to Artemis. Although it is modelled on the Homeric Hymn to Apollo, as demonstrated by Fain ${ }^{12}$, in this composition one may recognize the Homeric Poems as yet again the underlying architext of the poem. It is one of the hilarious hymns by Callimachus, in which the goddess Artemis is first presented as an infant, sitting on her father Zeus' knees, making all sorts of demands, while she repeatedly says, like any human child: give me, give me, give me. What does she ask for? She asks for the attrib-

\footnotetext{
${ }^{8}$ Cf. MORRISON, 2007: 103.

${ }^{9}$ An interesting analysis of this hymn may be found in DEPEW, 1989: 75-115. The author points out how Callimachus distances himself from the models for the composition of his hymn and convincingly argues that «the explananda for which the myth provides an aetiological account are not elements of experienced religion at all, but, revealingly, names» (p. 76). SLINGS, 2004 has a different approach, reading the Hymn to Delos as a poetic reflection on poetry. Cf. also MINEUR, 1984.

${ }^{10}$ Of course, the constant use of aetiology in the Hymns has other layers of meaning. DEPEW, 1989 demonstrates the literary meaning of aetiology in Callimachus' hymnical poetry. HOPKINSON, 1984: 141 sustains that both aetiology and etymology - references to the origin of words scattered throughout the Hymn to Zeus - are a display of poetic authoritativeness.

${ }^{11}$ Several titles of other lost prose works by Callimachus, such as Foundations of Islands and Cities and their Names or On the Names of Fish, refer to the author's interest in names.

${ }^{12}$ FAIN, 2004: 47. Cf. BING; UHRMEISTER, 1994.
} 
utes which will later on define her as goddess: eternal virginity, as many names as her brother Apollo, a choir of sixty Oceanides, twenty maidens to accompany her on the hunt, all the mountains, cities, etc, etc. After the direct discourse of little Artemis, the narrator describes how she tries to grab her father's beard, following the rules of supplication, but in vain, because she is so small. Zeus reacts as any father proud of his offspring. Callimachus depicts Zeus answering her with a smile, saying (29-30): «When goddesses bear me children like this, little need I heed the wrath of jealous Hera». He grants her everything and even more than she asked for, and the scene closes with the verse (39): «So he spoke and bent his head to confirm his words». There are very clear reminiscences of the episode in chapter I of the Iliad, in which Thetis comes before Zeus as a suppliant at the Olympus, grasping his beard with her right hand and clinging to his knees with her left hand: the detailed ritual, the god's allusion to Hera's jealousy, the narrator's choice of ending of the scene by depicting Zeus' nod of approval. In the Iliad Zeus's nod is described in quite a comic tone, when the narrator says that the god's ambrosian hair flies in the wind and the vast Olympus shakes.

There are other resonances of Homer's Iliad. Afterwards, little Artemis travels from the Olympus to the forge of the Cyclops, of whom she asks new weapons; in the Iliad, Thetis also asks Hephaestus to create a set of new weapons for Achilles. Accompanied by the nymphs that her father had granted her (note that Thetis dwells among the Nymphs of the Ocean, although she goes alone to Hephaestus' forge), Artemis visits the blacksmith Cyclopes, one-eyed monstrous creatures, whose work stained and blackened them and whose anvils clanged frightfully loud. The nymphs are so terrified by this sight that they dare not look straight at the creatures. The narrator comments:

No shame to them! On those not even the daughters of the Blessed look without shuddering. Though long past childhood's years. But when any of the maidens doth disobedience to her mother, the mother calls the Cyclopes to her child-Arges or Steropes; and from within the house comes Hermes, stained with burnt ashes. And straightway he plays bogey to the child, and she runs into her mother's lap, with her hands upon her eyes.

While Homer would use a simile, comparing the nymphs' fear with the fright felt by infants when their mothers threaten them with the bogeyman, Callimachus sets a fully human, domestic and familial environment, without the use of any comparative link. Of course, also echoing the typical Homeric work, the fear felt by the nymphs further highlights the fearlessness expressed by Artemis. Nausicaa, in the Odyssey, is the only one who courageously stands before the castaway Ulysses, unwashed and naked, who had been hiding in the reeds; all her maidens flee in terror. Ulysses, like the narrator himself had done before, justly compares her to Artemis, who outshines her dancing companions.

In order to emphasize the dauntlessness of the little goddess, Callimachus tells one 
more story, of how three-year-old Artemis had gone with her mother to visit Hephaestus; not only had she bravely sat on his lap, but plucked out a handful of his chest hair, with such force that to this day the blacksmith god's chest remained hairless.

I will mention just one more scene to complete this domestic and familial portrait of the Olympus that Callimachus undoubtedly assimilated from Homer. When the goddess returns to the Olympus, carrying her weapons, back from the hunt, she is greeted by, amongst others, Hercules, who is anxiously at the gates: he is waiting for her to bring food, because in spite of his demi-god condition, he remains a big glutton, as the narrator comments later on. The reaction of the gods to the former hero's gluttony is laughter, an endless ( $\alpha \lambda \lambda \eta \eta \tau$ \% $)$ laughter, in an obvious allusion to the undying laughter of Homer's Olympian

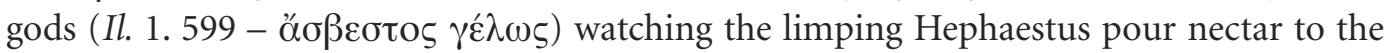
guests at the divine feast.

In fact, the scenes set at the Olympus in chapter I of the Iliad are among the most hilarious ones in the Homeric Poems; it is therefore no surprise that Callimachus evokes them on multiple levels in this text, which to me is a hommage paid by the poet from Alexandria to Homer. This playful parody extends to the poet's own status as narrator and erudite. Callimachus seems to joke about himself and his erudition ${ }^{13}$. Despite the aesthetic principles that the poet lays down in several fragments of his work and in the Book of Hymns - namely the well-known end of the Hymn to Apollo, in which the poet defends formal purity and thus rejects long-winded compositions, written in Homeric fashion -, he clearly surrenders himself to the charm of Homer's work, regardless of eventual inconsistencies in his long poems. Callimachus even makes small mistakes, apparently with the intent of playing a joke on himself and, of course, on the reader. For example, in the Hymn to Artemis he says that the belt and weapons forged for the goddess are made of gold, using the Greek adjective for "golden» no less than three times - and further down in the text he asks (113): «And how often goddess, didst thou make trial of thy silver bow?». It is an obvious but distorted reminiscence of Homer, for in the Iliad it is Apollo who has the epithet of «god of the silver bow». This inconsistency is also a conscious and deliberate parodic imitation of Homer's and Hesiod's sometimes mechanical and seemingly meaningless use of formulae and epithets.

The way how the poet playfully selects and manipulates his data demonstrates a keen interest in these stories, especially in the ancient form of narrative received from Homer, Hesiod and other poets in the past.

This allows me to approach another issue that may be inferred from the poet's stance in the Hymns. Callimachus certainly did not wish for myths to remain lifeless in the writ-

\footnotetext{
13 This is precisely what HUTCHINSON, 1988: 31 argues, in his analysis of fr. 75: «By dramatizing himself and playing with his character, Callimachus makes it as clear as possible that his professed involvements as scholar are treated in the poetry with the keenest awareness and the easiest detachment». Cf. MORRISON, 2007: 104.
} 
ings of mythographers, but rather to keep them alive through poetry. In fact, only the work of poets could rescue myth from the draining destructive effects of allegorical (or akin) interpretations.

In the first of his Iambi ${ }^{14}$, Callimachus brings back from Hades the ancient poet, (6th century B.C.) Hipponax, who integrated, alongside Archilocus and Semonides, the canon of iambographers fixed by the Alexandrian sages. The Iamb is quite fragmented, like the rest, but it contains a very important reference to Euhemerus, a mythographer from the late 4 th century and early 3 th century. Euhemerus' written prose depicted the gods from mythical narratives as powerful men from the past who had become divinized over time by peo-

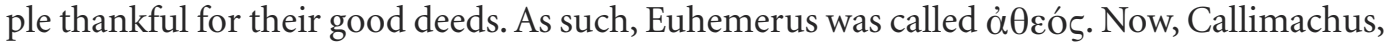
through Hipponax's mouth, alludes to him in very negative terms, calling his writings

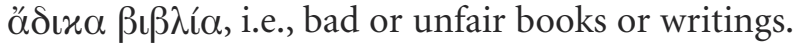

It seems to me that this allusion, in spite of being brief, clearly signals Callimachus' dislike of rationalizing approaches to traditional narratives, which were very common at a time when myth and poetry had long ceased to be the one and the same. It is likely that the work of a certain Palephatus ${ }^{15}$ was also known at the time; Palephatus was possibly contemporaneous with Aristoteles and followed the same path of rationalizing stories protagonized by heroes from the past, making them more credible according to factual and historical truth standards.

However, Callimachus' Hymns tread a very different path. All of his work encompasses the notion that the poet's role is not, no matter how erudite he may be, to rationally interpret myths, but to tell them and to invent new stories. This amounts to saying that the poet should give poetic shape to the stories that have not yet been dignified as myths, through a process of perennial dialogue with the cultural tradition in which he recognizes himself and from which he inherited the art that enchants and hence persuades.

\footnotetext{
${ }^{14}$ On this composition and the meaning of Hipponax's presence in it (vide KERKHECKER, 1999). In his analysis of Iamb 4 (LOWELL, 2001: 78) says that «Hipponax was a perfect model for Callimachus' participation in the literary controversy in which the historical Callimachus was apparently engaged and in which the poet Callimachus represents himself as engaged in well-known passages of the Aitia, in the Hymn to Apollo, and in Epigram 28 Pf».

${ }^{15}$ On this author, see STERN, 1999.
} 